\title{
Molecular Mapping of YrSP and Its Relationship with Other Genes for Stripe Rust Resistance in Wheat Chromosome 2BL
}

\author{
J. Y. Feng, M. N. Wang, X. M. Chen, D. R. See, Y. L. Zheng, S. M. Chao, and A. M. Wan
}

First author: Biotechnology and Nuclear Technology Research Institute, Sichuan Academy of Agricultural Sciences, Chengdu, Sichuan, 610061, P.R. China; first, second, third, fourth, and seventh authors: Department of Plant Pathology, Washington State University, Pullman 991646430; first and fifth authors: Triticeae Research Institute, Sichuan Agricultural University, Northeast Road No. 555, Wenjiang, Chengdu, Sichuan 611130, P.R. China; third and fourth authors: United States Department of Agriculture-Agricultural Research Service (USDA-ARS), Wheat Genetics, Quality, Physiology and Disease Research Unit, Pullman, WA 99164-6430; and sixth author: USDA-ARS, Cereal Crops Research, Fargo, ND 58102-2775.

Accepted for publication 8 April 2015.

\begin{abstract}
Feng, J. Y., Wang, M. N., Chen, X. M., See, D. R., Zheng, Y. L., Chao, S. M., and Wan, A. M. 2015. Molecular mapping of YrSP and its relationship with other genes for stripe rust resistance in wheat chromosome 2BL. Phytopathology 105:1206-1213.

Stripe rust, caused by Puccinia striiformis f. sp. tritici, is an important disease of wheat worldwide. Resistance is the best way to control the disease. $Y r S P$, a gene originally from 'Spaldings Prolific' wheat and providing resistance to a broad spectrum of races, is used for differentiating P. striiformis f. sp. tritici races but its chromosomal location is not clear. To map $Y r S P$, a near-isogenic line (AvSYrSPNIL) was backcrossed to the recurrent parent, Avocet $\mathrm{S}$. Genetic analysis of the $\mathrm{BC}_{7} \mathrm{~F}_{1}, \mathrm{BC}_{8}, \mathrm{BC}_{7} \mathrm{~F}_{2}$, and $\mathrm{BC}_{7} \mathrm{~F}_{3}$ progenies confirmed a single dominant gene for resistance. In total, $182 \mathrm{BC}_{7} \mathrm{~F}_{2}$ plants and their derived $\mathrm{BC}_{7} \mathrm{~F}_{3}$ lines were phenotyped with an avirulent $P$. striiformis $\mathrm{f}$. sp. tritici race and genotyped with simple-sequence

site (STS) markers. A linkage map was constructed with 3 SSR, 17 SNP, and 3 STS markers covering 23.3 centimorgans (cM). Markers IWA638 and $d p 269$ were $0.6 \mathrm{cM}$ proximal and $1.5 \mathrm{cM}$ distal, respectively, to $\mathrm{YrSP}$. The gene was mapped in chromosome bin $2 \mathrm{BL}-\mathrm{C}-0.5$, physically within the proximal $50 \%$ of the chromosome $2 \mathrm{BL}$ arm. Allelism tests based on $\mathrm{F}_{2}$ phenotypes indicated that $\mathrm{YrSP}$ is closely linked to but not allelic with genes $Y r 5, Y r 7, Y r 43, Y r 44$, and $Y r 53$. Infection type data from tests with 10 historical and currently predominant $P$. striiformis $\mathrm{f}$. sp. tritici races in the United States also demonstrated differences in specificity between $Y r S P$ and the other genes. The specificity of $Y r S P$ is useful in differentiating $P$. striiformis $\mathrm{f}$. sp. tritici races and studying the plant-pathogen interactions, and the information of chromosomal location of the gene and its tightly linked markers should be useful in developing resistant cultivars when combined with other genes for resistance to stripe rust.
\end{abstract} repeat (SSR), single-nucleotide polymorphism (SNP), and sequence-tagged
Wheat stripe rust, caused by Puccinia striiformis Westend. f. sp. tritici Erikss., is one of the most destructive fungal diseases of wheat worldwide (Stubbs 1985; Wellings 2011). The disease usually occurs in cool and temperate regions and significantly affects yield and grain quality when wheat varieties are severely infected (Chen $2005,2014)$. Many measures have been used to control the disease, including cultural practices and chemical application. Compared with these methods, resistant cultivars are considered the most effective and economic means to control the disease (Chen 2005, 2013, 2014; Line 2002).

Sets of differential lines with different resistance genes are used for identifying $P$. striiformis $\mathrm{f}$. sp. tritici races. In order to improve differentiation and maintain relevance over time, genotypes in a differential set may be changed or supplemented when new races cannot be differentiated using preexisting sets. Gassner and Straib (1932) proposed the first differential set, which included 15 varieties of common wheat, Triticum dicoccum, barley, and rye for differentiating races of $P$. striiformis. Although this set of differentials of multiple crops was used up to the 1980s, it did not adequately differentiate races of either $P$. striiformis $\mathrm{f}$. sp. tritici or the barley

Corresponding author: X. M. Chen; E-mail address: xianming@wsu.edu

*The $\boldsymbol{e}$-Xtra logo stands for "electronic extra" and indicates that one supplementary figure and two supplementary tables are published online.

http://dx.doi.org/10.1094/PHYTO-03-15-0060-R

This article is in the public domain and not copyrightable. It may be freely reprinted with customary crediting of the source. The American Phytopathological Society, 2015 stripe rust pathogen (P. striiformis f. sp. hordei) (Chen et al. 1995; Stubbs 1985). Johnson et al. (1972) introduced a dual set of only wheat genotypes described as "world" and "European" differentials, the latter including 'Spaldings Prolific' ( $Y r S P$ ). This set of differentials was adopted in many countries in Europe and other continents (de Vallavieille-Pope and Line 1990; Wellings and McIntosh 1990). In China, India, and the United States, different sets of wheat genotypes were selected for differentiating $P$. striiformis $\mathrm{f}$. sp. tritici races. The use of different differential sets in different countries has both advantages and disadvantages. Whereas a common set enables closer comparisons globally, more local sets tend to maintain historical continuity within regions and can be managed with greater relevance to the host cultivar genetic variation within those regions. An overriding problem with both approaches is the incomplete knowledge of the genetic basis of resistance both within and between regions. In order to achieve a greater genetic relevance, Wan and Chen (2014) recently established a new set of wheat differentials based on the Avocet S (AvS) nearisogenic lines developed in Australia, as well as single gene lines developed in the United States.

Spaldings Prolific, with resistance gene $\mathrm{YrSP}$, has been used to differentiate races in Europe and elsewhere (Johnson et al. 1972; Stubbs 1988; Wellings and McIntosh 1990). Stripe rust resistance in the wheat genotype has been studied for more than 60 years. Manners (1950) and Stubbs (1967) reported that light and temperature affected the stripe rust reaction of Spaldings Prolific. de Vallavieille-Pope and Line (1990) observed that Spaldings Prolific had low infection types (IT) when scored earlier and high IT when scored later in monocyclic inoculation tests with some U.S. races. Straib (1934) and Allan and 
Purdy (1970) reported that resistance in Spaldings Prolific to European race 4 (40E8 or 104E9) and North American race 61-1 was conferred by a single dominant gene in each instance. In contrast, Calonnec et al. (1996) reported three genes for resistance in Spaldings Prolific, all three conferring resistance to race $2 \mathrm{E} 16$ and only two of them effective against race 43E138. A gene for resistance to stripe rust in Spaldings Prolific, designated as $\mathrm{YrSP}$, was tentatively located on chromosome 2BS (Gosal 2000; McDonald et al. 2004), and Guan et al. (2005) mapped a gene $(\mathrm{YrSpP})$ in the same variety on chromosome 2BL. We presume that $Y r S P$ and $Y r S p P$ are the same gene even if the chromosomal location is unclear (McIntosh et al. 2013).

The YrSP near-isogenic line AvSYrSPNIL was developed by backcrossing Spaldings Prolific and AvS in Australia (Wellings et al. 2004). AvSYrSPNIL was resistant (IT 0 to 2, severity 0 to 5\%) in our germplasm nurseries and similar in response to Spaldings Prolific in various locations in the United States from 2003 to 2006, except for a reaction of IT 5 and 10\% severity on Spaldings Prolific at Pendleton, OR in 2006. Susceptible reactions on both host lines appeared first in California in 2007 and, since then, a range of reactions in different locations was observed, with $100 \%$ severity at some locations near Pullman, WA in 2011 and 2012 (X. M. Chen, unpublished data). Since AvSYrSPNIL was included in the new set of $Y r$ single-gene differentials in 2010, the frequencies of virulence to $\mathrm{YrSP}$ have ranged from $3.4 \%$ in 2010 to $9.8 \%$ in 2013 (Wan and Chen 2014) (A. M. Wan and X. M. Chen, unpublished data). Among the 84 races identified in the United States with the new set of $18 \mathrm{Yr}$ single-gene differentials, $9(10.7 \%)$ were virulent to $\mathrm{YrSP}$; and, of 55 races identified in other countries, 8 (14.5\%) were virulent (SharmaPoudyal et al. 2013; Wan and Chen 2014) (A. M. Wan and X. M. Chen, unpublished data). The gene is still useful in developing striperust-resistant cultivars in combination with other resistance genes. The objectives of this study were to map $\mathrm{YrSP}$ in AvSYrSPNIL and to determine its relationship to other $Y r$ genes mapped to chromosome 2BL. The tightly linked markers for $Y r S P$ should be useful in markerassisted selection (MAS) for pyramiding the gene with other effective resistance genes to develop wheat cultivars with durable resistance to stripe rust.

\section{MATERIALS AND METHODS}

Plant materials and development of genetic populations. Seed of AvSYrSPNIL, a $\mathrm{BC}_{6}$ line developed by backcrossing Spaldings Prolific (the resistant donor parent) to AvS in the Plant Breeding Institute, University of Sydney, were kindly provided by Dr. Colin Wellings. AvS, an Australian spring wheat genotype, is susceptible to almost all $P$. striiformis f. sp. tritici races identified in the United States and many other countries (Sharma-Poudyal et al. 2013; Wan and Chen 2014).

In order to study the genetic basis of resistance in AvSYrSPNIL, a cross was made between $\mathrm{AvS}$ and AvSYrSPNIL. $\mathrm{BC}_{7} \mathrm{~F}_{2}$ seed harvested from a single $\mathrm{BC}_{7} \mathrm{~F}_{1}$ plant were planted in the greenhouse, and $182 \mathrm{BC}_{7} \mathrm{~F}_{2: 3}$ lines were produced. A further backcross was made to $\mathrm{AvS}$ and $\mathrm{BC}_{8} \mathrm{~F}_{2}$ lines were produced in the greenhouse. Two parents, $\mathrm{BC}_{7} \mathrm{~F}_{1}, \mathrm{BC}_{7} \mathrm{~F}_{2}, \mathrm{BC}_{7} \mathrm{~F}_{3}$, and $\mathrm{BC}_{8} \mathrm{~F}_{2}$ seedling lines were tested in the greenhouse to determine the inheritance of resistance to stripe rust in AvSYrSPNIL.

Because $\operatorname{Yr} 5, \operatorname{Yr} 7, \operatorname{Yr} 43, \operatorname{Yr} 44, \operatorname{Yr} 53$, and $\operatorname{YrSP}$ were previously reported on chromosome 2B (McIntosh et al. 1995, 2013), lines AvSYr5NIL (Yr5), AvSYr7NIL (Yr7), IDO377s (Yr43), Zak (Yr44), and AvS/PI 480148F -128 (Yr53) were crossed with AvSYrSPNIL and $F_{2}$ populations of 481 to 544 plants from each of these crosses were used to test for linkage with $\mathrm{YrSP}$. 'Chinese Spring' (CS) and its nullitetrasomic or monotetrasomic lines, ditelosomic 2BL line, and 2BL deletion lines (Del2BL-4, Del2BL-5, Del2BL-6, and Del2BL-10) (Endo and Gill 1996; Sears 1966; Sears and Sears 1978) were used in marker tests to localize the specific position of $Y r S P$. In total, 77 wheat cultivars and breeding lines, which do not have $\mathrm{YrSP}$ based on their pedigrees and tests with
P. striiformis f. sp. tritici races virulent or avirulent to the gene, were tested with the markers flanking $\operatorname{YrSP}$ to determine their usefulness in MAS for incorporating the gene into various wheat backgrounds.

Stripe rust tests. Ten $P$. striiformis f. sp. tritici races, representing predominant U.S. races since the 1960s (Line and Qayoum 1992; Wan and Chen 2012), and race PST-151, which has the widest virulence range, were used to test AvS and AvSYrSPNIL for reaction to stripe rust (Table 1). Race PST-100 (avirulent on AvSYrSPNIL) was used to test the various segregating materials. Urediniospores of each isolate were increased on $\mathrm{AvS}$, and its virulence and avirulence pattern was confirmed by testing on the 20 U.S. differential lines following procedures as previously described (Wan and Chen 2012). Inoculations were made with fresh urediniospores mixed with talc at a 1:20 ratio when plants were at the two-leaf stage. The inoculated plants were kept in a dew chamber for $24 \mathrm{~h}$ at $10^{\circ} \mathrm{C}$ and then moved to a growth chamber, with the low temperature profile set with a diurnal temperature cycle gradually changing between $4^{\circ} \mathrm{C}$ at 2:00 A.M. and $20^{\circ} \mathrm{C}$ at 2:00 P.M. (Chen and Line 1995). IT were recorded using the 0 -to- 9 scale described by Line and Qayoum (1992) 20 days after inoculation.

DNA extraction and polymerase chain reaction amplification. Genomic DNA was extracted from leaf tissue of each $\mathrm{BC}_{7} \mathrm{~F}_{2}$ plant or parent using the cetyltrimethylammonium bromide method (Riede and Anderson 1996). DNA was dissolved in Tris-EDTA buffer (10 mM Tris- $\mathrm{HCl}$ and $1 \mathrm{mM}$ EDTA, $\mathrm{pH}$ 8.0). DNA quality was determined using $1.0 \%$ agarose gel electrophoresis, and the DNA concentration was measured using NanoDrop ND-1000 (Thermo Scientific, Wilmington, DE). The stock DNA solution was diluted to $25 \mathrm{ng} / \mu \mathrm{l}$ with sterile deionized distilled (dd) $\mathrm{H}_{2} \mathrm{O}$ for use as template in polymerase chain reaction (PCR).

Simple-sequence repeat (SSR) markers were used to map $Y r S P$. PCR was performed in volumes of $12 \mu \mathrm{l}$ comprising $4 \mu \mathrm{l}(100 \mathrm{ng})$ of template DNA, $1.2 \mu$ of $10 \times$ buffer (with $1.5 \mathrm{mM} \mathrm{MgCl}_{2}$ ), $0.48 \mu \mathrm{l}$ of $\mathrm{MgCl}_{2}(25 \mathrm{mM}), 0.96 \mu \mathrm{l}$ of mixed dNTP with $2.5 \mathrm{mM}$ each, $0.24 \mu \mathrm{l}$ of M13 primer $(10 \mu \mathrm{M})$ with fluorescent dye, $0.12 \mu \mathrm{l}$ of Taq DNA polymerase $(5 \mathrm{U} / \mu \mathrm{l}), 0.06 \mu \mathrm{l}$ of forward primer with M13 tail $(10 \mu \mathrm{M}), 0.3 \mu \mathrm{l}$ of reverse primer $(10 \mu \mathrm{M})$, and $4.64 \mu \mathrm{l}$ of sterilized $\mathrm{ddH}_{2} \mathrm{O}$. Buffer, dNTP, and Taq DNA polymerase were purchased from Promega Corp. (Madison, WI). M13 fluorescent primers were

TABLE 1. Infection types of Avocet S (AvS) and AvSYrSPNIL (YrSP) produced by 10 races of Puccinia striiformis f. sp. tritici under controlled conditions

\begin{tabular}{llcc}
\hline & \multicolumn{1}{c}{ Virulence formula $^{\mathrm{b}}$} & \multicolumn{2}{c}{$\begin{array}{c}\text { Infection } \\
\text { type }^{\mathrm{a}}\end{array}$} \\
\cline { 3 - 5 } Race & \multicolumn{1}{c}{ AvS } & YrSP \\
\hline PST-3 & 1,3 & 8 & 1 \\
PST-17 & $1,2,3,9,11$ & 8 & 1 \\
PST-43 & $1,3,4,5,12,14$ & 8 & 1 \\
PST-45 & $1,3,12,13,15$ & 8 & 1 \\
PST-78 & $1,3,11,12,16,17,18,19,20$ & 8 & 1 \\
PST-100 & $1,3,8,9,10,11,12,16,17,18,19,20$ & 8 & 1 \\
PST-114 & $1,3,4,8,9,10,11,12,14,16,17,18,19,20$ & 8 & 1 \\
PST-116 & $1,3,4,5,8,9,10,11,12,14,16,17,18,19,20$ & 8 & 1 \\
PST-127 & $1,2,3,5,6,8,9,10,11,12,13,15,16,17,18,19,20$ & 8 & 8 \\
PST-139 & $1,2,3,5,6,8,9,10,11,12,13,15,17,18,19$ & 8 & 1 \\
PST-151 & $1,2,3,4,5,6,8,9,10,11,12,13,14,15,16,17,18,19,20$ & 8 & 8
\end{tabular}

a Infection types were scored based on a 0-to-9 scale (Line and Qayoum 1992).

b Virulence formulae are based on reactions on the following 20 wheat genotypes used to differentiate races of $P$. striiformis $\mathrm{f}$. sp. tritici in the United States: 1 = Lemhi $(Y r 21), 2=$ Chinese $166(Y r 1), 3=$ Heines VII $(Y r 2$ and YrHVII), 4 = Moro (Yr10 and YrMor), $5=$ Paha (YrPa1, YrPa2, and YrPa3), $6=$ Druchamp $(Y r 3 a, Y r D$, and $Y r D r u), 7=$ AvSYr5NIL $(Y r 5), 8=$ Produra $(Y r P r 1$ and YrPr2), $9=$ Yamhill $(Y r 2, Y r 4 a$, and YrYam $), 10=$ Stephens $(Y r 3 a$, $Y r S$, and $Y r S t e), 11=$ Lee $(Y r 7, Y r 22$, and $Y r 23), 12=$ Fielder $(Y r 6$ and $Y r 20)$, $13=$ Tyee $($ YrTye $), 14=$ Tres $(Y r T r 1$ and $Y r T r 2), 15=$ Hyak $(Y r 17$ and $Y r T y e)$, $16=$ Express $(Y r E x p 1$ and $Y r E x p 2), 17=\operatorname{AvSYr8NIL~}(Y r 8), 17=$ AvSYr9NIL $(Y r 9), 19=$ Clement $(Y r 9$ and $Y r C l e)$, and $20=$ Compair $(Y r 8$ and $Y r 19)$ (Chen et al. 2010; Wan and Chen 2012). 
ordered from Applied Biosystems (Grand Island, NY). SSR primers developed by Röder et al. (1998) and Somers et al. (2004) were synthesized by Sigma-Aldrich Inc. (St. Louis).

PCR was performed in an ABI-9700 thermal cycler, programmed for 5 min of initial denaturation followed by 42 cycles, each cycle consisting of $1 \mathrm{~min}$ at $94^{\circ} \mathrm{C}, 1 \mathrm{~min}$ at 50 to $65^{\circ} \mathrm{C}$ depending on primers, and $1 \mathrm{~min}$ at $72^{\circ} \mathrm{C}$, followed by an extra extension of $10 \mathrm{~min}$ at $72^{\circ} \mathrm{C}$. PCR products were detected on ABI capillary DNA sequencer 3730 (Applied Biosystems, Foster City, CA), and the genotypes were analyzed using GeneMarker (V2.2; SoftGenetics, LLC., State College, PA).

Bulk segregant analysis was used in initial SSR marker screening. Based on the IT data of $\mathrm{BC}_{7} \mathrm{~F}_{2}$ individual plants and corresponding $\mathrm{BC}_{7} \mathrm{~F}_{3}$ lines, 10 homozygous resistant and 10 homozygous susceptible $\mathrm{BC}_{7} \mathrm{~F}_{2}$ plants were selected to make resistant and susceptible bulks, respectively. The resistant and susceptible bulks were constructed with equal amount of DNA, as described previously (Michelmore et al. 1991). The DNA samples from Avs YrSPNIL, AvS, and the two bulks were used for screening markers associated with $\mathrm{YrSP}$.

To increase the marker intensity on wheat chromosome $2 \mathrm{~B}$, the wheat 9K single-nucleotide polymorphism (SNP) chip was used to screen AvSYrSPNIL and AvS, as described by Cavanagh et al. (2013). The wheat 9K SNP detection was conducted at the United States Department of Agriculture-Agricultural Research Service (USDA-ARS) Bio-Sciences Research Laboratory, Fargo, ND. In total, 40 polymorphic SNP markers were identified and used to test the $182 \mathrm{BC}_{7} \mathrm{~F}_{2}$ plants using a Sequenom MassArray system at the USDA-ARS, Wheat Genetics, Quality, Physiology, and Disease Research Unit (Pullman, WA).

Data analyses. Goodness-of-fit of observed data to theoretically expected segregation ratios was assessed using $\chi^{2}$ tests. The IT data for resistant $\times$ resistant crosses were used to calculate the genetic distance between two genes according to the Kosambi formulae: $f=p^{2} / 4$ and $d=1 / 4 \operatorname{In}[(1+2 p) /(1-2 p)]$, where $f$ is the observed frequency of susceptible $\mathrm{F}_{2}$ plants, $p$ is the recombination value, and $d$ is the map distance in morgans (Kosambi 1943). The standard error was estimated as the square root of $d x(1-d) / n$, where $n$ is the total number of $\mathrm{F}_{2}$ plants in the test.

Linkage analysis was conducted based on marker genotypes and response phenotypes of $\mathrm{BC}_{7} \mathrm{~F}_{2: 3}$ lines using software JoinMap 4.0 (Voorrips 2002). Markers were placed in the same linkage group, with a log of the likelihood threshold of 3.0. The Kosambi mapping function was used to convert recombination values to map distances (Kosambi 1943). The genetic map was drawn using software Mapdraw V2.1 (Liu and Meng 2003).

\section{RESULTS}

Genetic analysis of stripe rust resistance in AvSYrSPNIL. AvSYrSPNIL was highly resistant (IT 1) to all races, except PST-127 and PST-151, to which it was susceptible (IT 8). AvS was susceptible (IT 8) to all races (Table 1).

In the test with PST-100, the $\mathrm{BC}_{7} \mathrm{~F}_{1}$ plants were resistant, showing necrotic spots with trace to light sporulation (IT 3 to 4), indicating that the resistance in AvSYrSPNIL was partially dominant. The segregations of the $\mathrm{BC}_{7} \mathrm{~F}_{2}$ population and its derived $\mathrm{BC}_{7} \mathrm{~F}_{3}$ population showed that the resistance in AvSYrSPNIL was controlled by a single gene (Table 2).

Molecular markers and linkage map. The location of $\mathrm{YrSP}$ was previously reported as chromosome $2 \mathrm{~B}$ but the chromosome arm is unclear. Therefore, SSR markers covering chromosome 2B and sequence-tagged site (STS) markers linked to the $\mathrm{Yr} 5$ locus on the long arm of chromosome $2 \mathrm{~B}(2 \mathrm{BL})$ were screened on the parents and bulks to identify those associated with the $\mathrm{YrSP}$ locus. Of 62 SSR markers and 10 STS markers screened, 3 SSR (Xwmc441, Xgwm388, and Xwmc332) and 3 STS (PWC17/18, dp269, and Yr5STS7/8) markers were associated with the $Y r S P$ locus (Table 3). All six markers were codominant (Table 4). As an example, the fragments of Xwmc441, $181 \mathrm{bp}$ in AvSYrSPNIL and $191 \mathrm{bp}$ in AvS, are shown in Supplementary Figure S1. Because the three SSR markers were located in 2BL (Somers et al. 2004), we presumed that $\mathrm{YrSP}$ was also located in chromosome 2BL (Fig. 1A).

To determine the within-chromosomal location of $\mathrm{YrSP}$, the six markers were screened on CS and its 21 nulli- (or mono)tetrasomic lines, ditelosomic 2BL line, and 4 2BL deletion lines (del2BL-4, del2BL-5, del2BL-6, and del2BL-10). The CS alleles of the six markers were detected in all of these lines, except N2BT2A-CS (Supplementary Table S1). The results confirmed the location on 2BL and indicated that $\mathrm{YrSP}$ was in chromosome bin $2 \mathrm{BL}-\mathrm{C}-0.5$ (Fig. 1B).

To identify more closely linked markers, AvS and AvSYrSPNIL were screened for SNP markers using the wheat 9K SNP chip. In all, 40 SNP markers $(0.44 \%)$ were polymorphic and 11 (IWA series) located on $2 \mathrm{BL}$ were selected to test the $\mathrm{BC}_{7} \mathrm{~F}_{2}$ plants. All except

TABLE 2. Reactions of parents and progenies of cross AvS $\times$ AvSYrSPNIL tested with race PST-100 in seedling stage under controlled conditions and $\chi^{2}$ tests ${ }^{\mathrm{a}}$

\begin{tabular}{lrrrrr}
\hline & \multicolumn{3}{c}{ Number of plants or lines } & & \\
\cline { 2 - 6 } Generation & Res & Seg & Sus & Expected ratio (Res:Sus or Res:Seg:Sus) & $\chi^{2}$ \\
\hline AvSYrSPNIL $\left(\mathrm{BC}_{6}\right)$ & 15 & 0 & 0 & $1: 0$ & NA \\
AvS & 0 & 0 & 16 & $0: 1$ & NA \\
$\mathrm{BC}_{7} \mathrm{~F}_{1}$ & 3 & 0 & 0 & $1: 0$ & NA \\
$\mathrm{BC}_{7} \mathrm{~F}_{2}$ & 134 & 0 & 48 & $3: 1$ & NA \\
$\mathrm{BC}_{7} \mathrm{~F}_{3}$ & 44 & 90 & 48 & $1: 2: 1$ & 0.18 \\
$\mathrm{BC}_{8}$ & 14 & 0 & 16 & $1: 1$ & 0.67 \\
\hline
\end{tabular}

${ }^{\mathrm{a}}$ Res $=$ resistant, Seg = segregating, Sus = susceptible, and NA = not applicable.

TABLE 3. Simple-sequence repeat (SSR) primers and $\operatorname{Yr} 5$ sequence-tagged site (STS) primers used to identify markers for the stripe rust resistance gene in the population of cross Avocet $\mathrm{S} \times$ AvSYrSPNIL

\begin{tabular}{|c|c|c|c|c|}
\hline \multirow[b]{2}{*}{ Primer } & \multicolumn{2}{|c|}{ Primer sequence $\left(5^{\prime}-3^{\prime}\right)$} & \multirow[b]{2}{*}{$\operatorname{Tm}\left({ }^{\circ} \mathrm{C}\right)^{\mathrm{a}}$} & \multirow[b]{2}{*}{ Reference } \\
\hline & Forward & Reverse & & \\
\hline Xwmc441 & TCCAGTAGAGCACCTTTCATT & ATCACGAAGATAAACAAACGG & 61 & Somers et al. 2004 \\
\hline Xgwm388 & CTACAATTCGAAGGAGAGGGG & CACCGCGTCAACTACTTAAGC & 60 & Röder et al. 1998 \\
\hline$d p 269$ & CTGCTGTCACCGCTCTCC & AGTCACACGCCCTACTCTCC & 55 & Fang et al. 2008 \\
\hline $\operatorname{Yr} 5 S T S 7 / 8$ & GTACAATTCACCTAGAGT & GCAAGTTTTCTCCCTATT & 56 & Chen et al. 2003 \\
\hline$P W C 17 / 18$ & GGAAACTAACTGCTGGCAGC & CCGGGTATTATCTGTATTCC & 55 & This study \\
\hline
\end{tabular}

a Annealing temperature. 
TABLE 4. Fragment sizes or polymorphic nucleotide sites of markers linked to the $Y r S P$ locus and $\chi^{2}$ tests of markers segregating in the mapping population of AvS $\times$ AvSYrSPNIL

\begin{tabular}{|c|c|c|c|c|c|}
\hline \multirow[b]{2}{*}{ Marker ${ }^{\mathrm{b}}$} & \multirow[b]{2}{*}{ Primer pair } & \multicolumn{2}{|c|}{ Size (bp) or nucleotide ${ }^{a}$} & \multirow[b]{2}{*}{$\chi^{2}(1: 2: 1)$} & \multirow[b]{2}{*}{$P$ value } \\
\hline & & AvSYrSPNIL & $\mathrm{AvS}$ & & \\
\hline Xwmc441 & WMC441F/R & 181 & 191 & 4.17 & 0.12 \\
\hline$P W C 17 / 18$ & $\mathrm{PWC} 17 / 18 \mathrm{~F} / \mathrm{R}$ & 242 & 265 & 5.42 & 0.07 \\
\hline Yr5STS7/8 & Yr5STS8/7 F/R & 505 & 492 & 1.57 & 0.46 \\
\hline Xgwm388 & GWM388 F/R & 230 & 226 & 3.95 & 0.14 \\
\hline Xwmc332 & WMC332 F/R & 184 & 191 & 7.04 & 0.03 \\
\hline IWA2872 & wsnp_Ex_B24135_33382318 & $\mathrm{T}$ & $\mathrm{C}$ & 2.09 & 0.35 \\
\hline IWA3075 & wsnp_Ex_B26818_36041748 & $\mathrm{T}$ & $\mathrm{C}$ & 2.09 & 0.35 \\
\hline IWA4866 & wsnp_Ex_c9025_15039930 & $\mathrm{T}$ & G & 3.13 & 0.21 \\
\hline IWA4900 & wsnp_Ex_c9345_15516291 & $\mathrm{G}$ & A & 1.60 & 0.45 \\
\hline IWA6121 & wsnp_JD_A6010_7167084 & $\mathrm{C}$ & $\mathrm{T}$ & 1.60 & 0.45 \\
\hline IWA6561 & wsnp_Ku_c15498_24122936 & $\mathrm{G}$ & A & 2.64 & 0.27 \\
\hline
\end{tabular}

a Sizes of SSR and STS markers include the 19-bp M13 sequence.

b Xwmc441, Xgwm388, and Xwmc332 are SSR markers (Röder et al. 1998; Somers et al. 2004); PWC17/18 (M. N. Wang, unpublished), Yr5STS7/8 (Chen et al. 2003), and $d p 269$ (Fang et al. 2008) are STS markers tightly linked to $\operatorname{Yr} 5$; and those with prefix IWA are single-nucleotide polymorphism (SNP) markers (Cavanagh et al. 2013).

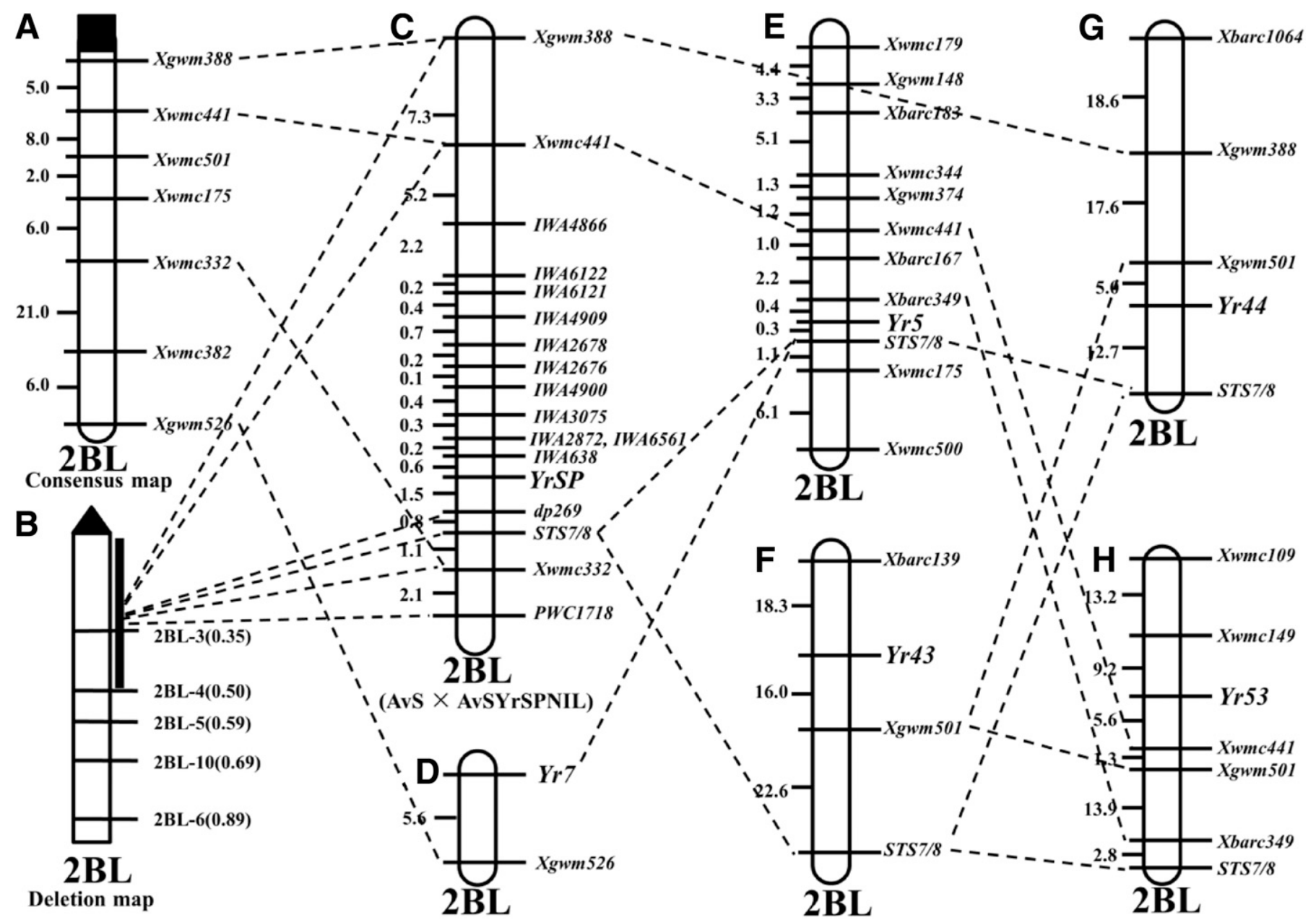

Fig. 1. Linkage map and chromosomal location of $Y r S P$ and comparisons with different linkage maps of other $Y r$ genes on the long arm of 2B (2BL). A, Consensus map of 2BL (Somers et al. 2004); B, deletion map of 2BL (Sourdille et al. 2004); C, Linkage map of YrSP; D, linkage map of $Y r 7$ (Yao et al. 2006); E, linkage map of $\operatorname{Yr} 5$ (Murphy et al. 2009); F, linkage map of Yr43 (Cheng and Chen 2010); G, linkage map of Yr44 (Sui et al. 2009; Cheng and Chen 2010); and H, linkage map of $\operatorname{Yr} 53$ (Xu et al. 2013). Dotted lines connected the same markers in different maps. 
$X w m c 332$ were normally inherited and linked with the $\mathrm{YrSP}$ locus and, hence, were suitable for linkage mapping (Table 4).

All markers listed in Table 4 were used to construct a linkage map for the $\mathrm{YrSP}$ locus based on the $\mathrm{BC}_{7} \mathrm{~F}_{2}$ genotypes (Fig. 1C). The nearest markers flanking $\mathrm{YrSP}$ were IWA638 (0.6 centimorgans [cM] proximal) and $d p 269$ (1.5 cM distal).

Relationship of $\mathrm{YrSP}$ with other $\mathrm{Yr}$ genes on $2 \mathrm{BL}$. To date, five permanently named $Y r$ genes- $Y r 5, Y r 7, Y r 43, Y r 44$, and Yr53-have been mapped to chromosome 2BL. In order to determine the relationship of $\operatorname{YrSP}$ with these genes, the reference lines were compared for differential reactions to $P$. striiformis f. sp. tritici races, tests of allelism, and closely linked SNP markers.

Five genotypes-AvSYr5NIL (Yr5), AvSYr7NIL ( $Y r 7)$, IDO377s (Yr43), Zak (Yr44), AvS/PI 484480F 7 -128 (Yr53), and AvSYrSPNIL ( $Y r S P$ )—were tested with 10 selected $P$. striiformis f. sp. tritici races. AvSYr5NIL and AvS/PI $484480 \mathrm{~F}_{7}-128$ were resistant to all races but with slightly different ITs. AvSYr7NIL was susceptible to all races, except resistant to PST-3. IDO377s was resistant to six races and Zak was resistant to three races. AvSYrSPNIL was resistant to all races, except PST-127 (Table 5). These results indicated that $Y r S P$ differed in specificity from the other five genes.

Susceptible $\mathrm{F}_{2}$ plants were identified in all five crosses between AvSYrSPNIL and each of the five lines. The segregations of resistant to susceptible plants in the $\mathrm{F}_{2}$ populations of these crosses did not fit $(P<0.0001)$ a 15:1 ratio, which is expected for two independent genes on different chromosomes, and, thus, indicated that $\mathrm{YrSP}$ was linked to all of the other five genes involved in the populations. Based on the frequencies of the susceptible plants, the genetic distances between $\mathrm{YrSP}$ and the other genes were estimated to be 12.6 to $18.6 \mathrm{cM}$ (Table 6).

To further compare $Y r S P$ with the other $Y r$ genes on chromosome 2BL, AvSYrSPNIL (YrSP), T. spelta album (Yr5), AvSYr5NIL (Yr5), AvSYr7NIL (Yr7), IDO377s (Yr43), Zak (Yr44), T. durum PI 480148 ( $Y r 53)$, and AvS/PI 480148 F $_{7}-128$ (Yr53) were tested with six SNP markers linked with YrSP. Markers IWA2872, IWA3973, and IWA6561 distinguished AvSYrSPNIL from all other lines, except IDO377s and Zak (Table 7). Markers IWA1489 and IWA6317 shared the same allele in AvSYrSPNIL, AvSYr7NIL, and Zak but different alleles were present in the other gene lines. Marker IWA6122 could not differentiate among AvSYrSPNIL, T. spelta album, and AvSYr7NIL but could differentiate AvSYrSPNIL from the remaining lines. Thus, when used in combination, these SNP markers could be used to distinguish AvSYrSPNIL from lines carrying the other $\mathrm{Yr}$ genes on 2BL. The SNP marker haplotypes, along with the response spectra and allelism tests, indicated that $Y r S P$ was different from other named $Y r$ genes in chromosome 2BL.

Polymorphism of $\mathrm{YrSP}$ markers in different wheat backgrounds. To determine how useful markers Xwmc332, dp269, and Xwmc441 might be in MAS to incorporate $\operatorname{YrSP}$ to wheat cultivars, 77 wheat cultivars and breeding lines were assayed with the markers. The specific band of $d p 269$ associated with $\operatorname{YrSP}$ was present in 28 genotypes and absent in 49 (Supplementary Table S2). For Xwmc441, eight genotypes had the target amplicon (89.61\% polymorphic). The expected amplicon of Xwmc332 was not present in 66 genotypes. Only two lines (OR2080156H and

TABLE 5. Infection types of wheat lines with $Y r$ genes located in the long arm of chromosome 2B tested with 10 races of Puccinia striiformis f. sp. tritici in the greenhouse

Infection types produced by $P$. striiformis f. sp. tritici races $^{\mathrm{a}}$

\begin{tabular}{|c|c|c|c|c|c|c|c|c|c|c|c|}
\hline Genotype & $Y r$ gene & PST-3 & PST-17 & PST-43 & PST-45 & PST-78 & PST-100 & PST-114 & PST-116 & PST-127 & PST-139 \\
\hline AvSYr5NIL & $\operatorname{Yr} 5$ & 1 & 1 & 1 & 1 & 1 & 1 & 1 & 1 & 1 & 1 \\
\hline AvSYr7NIL & $Y r 7$ & 2 & 8 & 8 & 8 & 8 & 8 & 8 & 8 & 8 & 8 \\
\hline IDO377s & $\operatorname{Yr} 43$ & 2 & 2 & 2 & 8 & 2 & 2 & 2 & 8 & 8 & 8 \\
\hline Zak & $\operatorname{Yr} 44$ & 2 & 8 & 2 & 2 & 8 & 8 & 8 & 8 & 8 & 8 \\
\hline AvS/PI480148F $\mathrm{F}_{7}-128$ & $\operatorname{Yr} 53$ & 2 & 2 & 2 & 2 & 2 & 2 & 2 & 2 & 2 & 2 \\
\hline AvSYrSPNIL & $Y r S P$ & 1 & 1 & 1 & 1 & 1 & 1 & 1 & 1 & 8 & 1 \\
\hline $\mathrm{AvS}$ & None & 8 & 8 & 8 & 8 & 8 & 8 & 8 & 8 & 8 & 8 \\
\hline
\end{tabular}

${ }^{a}$ Infection types were scored based on a 0-to-9 scale (Line and Qayoum 1992).

TABLE 6. Reactions of $\mathrm{F}_{1}$ and $\mathrm{F}_{2}$ progenies in allelism tests between the wheat lines with $\mathrm{YrSP}$ and five $\mathrm{Yr}$ genes located in the long arm of chromosome $2 \mathrm{~B}$

\begin{tabular}{|c|c|c|c|c|c|c|c|c|}
\hline \multirow[b]{2}{*}{ Cross $^{\mathrm{b}}$} & \multirow[b]{2}{*}{ Reaction of $F_{1}$ plants } & \multicolumn{3}{|c|}{ Number of $F_{2}$ plants $^{a}$} & \multirow[b]{2}{*}{$\chi^{2}(15: 1)$} & \multirow[b]{2}{*}{$P$} & \multirow[b]{2}{*}{ Recombinant rate } & \multirow[b]{2}{*}{ Distance $(\mathrm{cM})$} \\
\hline & & Total & Res & Sus & & & & \\
\hline $\operatorname{YrSP} / Y r 5$ & $\mathrm{R}$ & 522 & 520 & 2 & 30.7 & $3.0 \times 10^{-8}$ & 0.124 & $12.6 \pm 1.5$ \\
\hline$Y r S P / Y r 7$ & $\mathrm{R}$ & 506 & 502 & 4 & 25.7 & $3.9 \times 10^{-7}$ & 0.178 & $18.6 \pm 1.7$ \\
\hline YrSP/Yr44 & $\mathrm{R}$ & 535 & 532 & 3 & 29.6 & $5.4 \times 10^{-8}$ & 0.15 & $15.5 \pm 1.6$ \\
\hline YrSP/Yr53 & $\mathrm{R}$ & 481 & 479 & 2 & 27.9 & $1.3 \times 10^{-7}$ & 0.129 & $13.2 \pm 1.5$ \\
\hline
\end{tabular}

${ }^{\mathrm{a}}$ Res $=$ resistant and Sus $=$ susceptible.

${ }^{b} F_{1}$ and $F_{2}$ plants of all of the five crosses were tested with PST-3 that is avirulent to all of the $Y r$ genes.

TABLE 7. Single-nucleotide polymorphism (SNP) genotypes of AvSYrSPNIL and other wheat lines carrying $Y r$ genes in the long arm of chromosome 2B

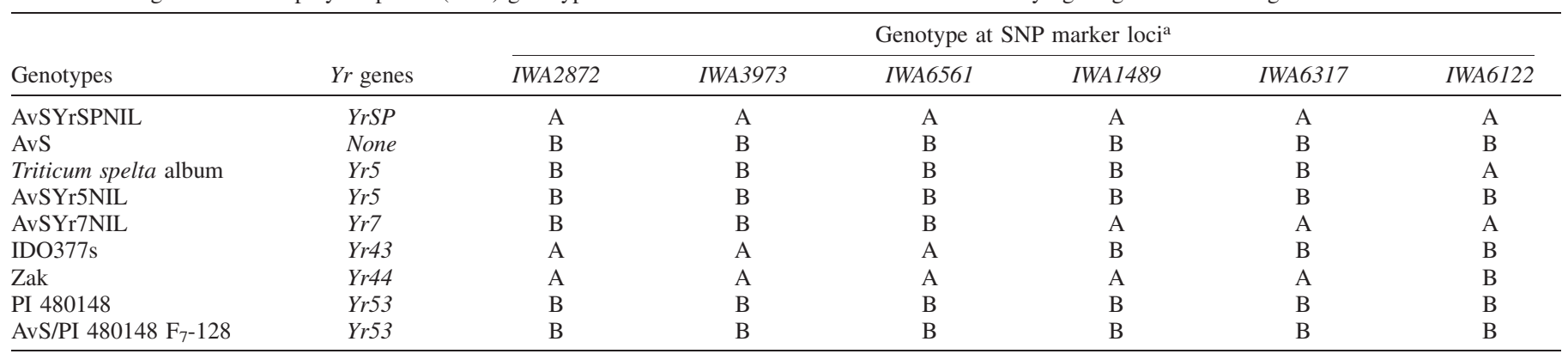

a $\mathrm{A}$ and $\mathrm{B}$ are used to designate the nucleotide type of AvSYrSPNIL and AvS, respectively. 
OR2080228H) lacking $\operatorname{YrSP}$ had all three expected amplicons, indicating that, when the markers are used together, there would be a $97.40 \%$ likelihood of identifying $\mathrm{YrSP}$ in wheat germplasm.

The wheat cultivars or breeding lines were also tested with five P. striiformis f. sp. tritici races in the seedling stage in the greenhouse. All wheat cultivars or lines had reaction patterns different from AvSYrSPNIL, except Glee, WB Hartline, and Malbee, which had patterns similar to AvSYrSPNIL. Lines OR2080156H and OR2080228H, with marker alleles in common with AvSYrSPNIL, had different reaction patterns. Thus, the combination of the marker and race test data indicates that none of the wheat cultivar or lines has $Y r S P$.

\section{DISCUSSION}

Spaldings Prolific is one of the earliest wheat varieties used to differentiate $P$. striiformis f. sp. tritici races (Gassner and Straib 1932; Stubbs 1985). The variety was reported to have a single gene (Allan and Purdy 1970; Straib 1934) or three genes (Calonnec et al. 1996) for resistance to stripe rust. Several studies attempted to find the chromosomal location of the single gene but whether the gene is in the long arm or short arm of chromosome 2B was not clear (Gosal 2000; Guan et al. 2005; McIntosh et al. 2013). Carrying a single gene for stripe rust resistance, the near-isogenic line AvSYrSPNIL derived from Spaldings Prolific has been selected as a differential to identify P. striiformis f. sp. tritici races (Wan and Chen 2014). The near-isogenic line is preferred over Spaldings Prolific for mapping the $Y r S P$ gene. In the present study, we confirmed that the line has a partially dominant gene conferring a high level of resistance against avirulent $P$. striiformis f. sp. tritici races. We constructed a high-resolution map with 23 markers covering $23.3 \mathrm{cM}$, with the flanking markers being $0.6 \mathrm{cM}$ proximal and $1.5 \mathrm{cM}$ distal to $\mathrm{YrSP}$. Using CS deletion lines, we placed the gene in chromosome bin 2BL-C-0.5. Based on differential rust responses, allelism tests, and molecular markers, $\mathrm{YrSP}$ is different from previously reported genes in chromosome 2BL.

Yan et al. (2003) mapped $Y r 5$ and Yao et al. (2006) reported $Y r 7$ in chromosome 2BL (Fig. 1D and E). $Y r 7$ is linked to SSR marker Xgwm526 at a genetic distance of $5.6 \mathrm{cM}$ (Fig. 1D) (Yao et al. 2006). Because this marker is most distal in the consensus 2BL map (Somers et al. 2004) and not present in the $Y r S P$ map, the distance between $Y r 7$ and $\mathrm{YrSP}$ could not be accurately determined. Zhang et al. (2009) found no susceptible line among $143 \mathrm{~F}_{3}$ lines of a cross between AvSYr7NIL (Yr7) and AvSYr5NIL (Yr5). They found that STS

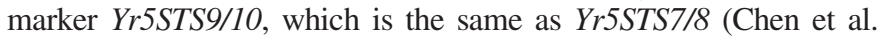
2003), is also in the $Y r 7$ line but of different alleles. Their data confirmed the location of $Y r 7$ in chromosome 2BL and tight linkage to the $\operatorname{Yr} 5 S T S 7 / 8$ or $\operatorname{Yr5STS} 9 / 10$ marker locus. Based on these results, they concluded that $Y r 7$ and $Y r 5$ were allelic or tightly linked. Using $506 \mathrm{~F}_{2}$ plants from a cross of AvSYrSPNIL and AvSYr7NIL, we found four susceptible plants, suggesting linkage of $18.6 \mathrm{cM}$ between $Y r S P$ and $Y r 7$. In our map, Yr5STS7/8 was $2.3 \mathrm{cM}$ distal to $Y r S P$ (Fig. 1C). The Yr5STS7/8 and Yr5STS 9/10 markers were converted from a single resistance gene analog polymorphic marker that was cosegregating with $\operatorname{Yr} 5$ (Yan et al. 2003; Chen et al. 2003) but later found to be $0.3 \mathrm{cM}$ from $\operatorname{Yr} 5$ (Fig. 1F) (Murphy et al. 2009). PWC1718 is an STS marker that was found to be closer to $\operatorname{Yr} 5$ than $Y r 5 S T S 7 / 8$ (M. N. Wang and X. M. Chen, unpublished data). In the present study, this marker was found $5.5 \mathrm{cM}$ and the $Y$ r $5 S T S 7 / 8$ marker $2.3 \mathrm{cM}$ distal to the $\mathrm{YrSP}$ locus in the mapping population (Fig. 1C). The present linkage map of $Y r S P$ and the Yr5 map of Murphy et al. (2009) share SSR marker Xwmc411, which is $3.6 \mathrm{cM}$ proximal to $\mathrm{Yr} 5$ and 11.4 proximal to $Y r S P$. The linkage estimates indicate that $Y r S P$ and $Y r 5$ are different but closely linked. Among $520 \mathrm{~F}_{2}$ plants of the AvSYrSPNIL $\times$ AvSYr5NIL cross, we identified two susceptible plants, indicating linkage of $12.6 \mathrm{cM}$ between $\mathrm{YrSP}$ and $\mathrm{Yr} 5$. Although this distance and that between $\mathrm{YrSP}$ and $\mathrm{Yr} 7$ were larger than the distances based on the markers, the order of the genes is consistent. Therefore, the three resistance genes must be at different loci, with $\mathrm{Yr} 7$ more distal to $Y r S P$ than $Y r 5$. The 11 SNP markers identified to be linked to YrSP were all mapped to chromosome 2B (Cavanagh et al. 2013). The order and distances among the markers in the present study were consistent with those reported by Cavanagh et al. (2013). The SNP markers confirmed the chromosomal location of $Y r S P$.

Marker $Y r 5 S T S 7 / 8$ is also linked to $Y r 43, Y r 44$, and $Y r 53$ (Fig. $1 \mathrm{~F}-\mathrm{H}$ ). It was $33.6 \mathrm{cM}$ from $Y r 43$ (Cheng and Chen 2010), $12.7 \mathrm{cM}$ from $\operatorname{Yr} 44$ (Sui et al. 2009), and 23.6 cM from Yr53 (Xu et al. 2013). The marker was only $2.3 \mathrm{cM}$ from $Y r S P$. Based on this marker and other markers in the linkage map for $\operatorname{YrSP}, \operatorname{Yr} 5 S T S 7 / 8$ was approximately $8.1 \mathrm{cM}$ from $\operatorname{Yr} 43,6.0 \mathrm{cM}$ from $\mathrm{Yr} 44$, and $18.6 \mathrm{cM}$ from $\operatorname{Yr} 53$. In addition, $X g w m 388$ was reported to be $22.6 \mathrm{~cm}$ from Yr44 (Fig. 1G) (Sui et al. 2009) and Xwmc411 was 5.6 cM from Yr53 (Fig. 1H) (Xu et al. 2013). In our present map, Xgwm388 and $X w m c 411$ were 17.8 and $10.5 \mathrm{cM}$, respectively, from $\mathrm{YrSP}$. The differences in distance could be due to different genetic backgrounds of the wheat lines. However, the gene order and relative distances were consistent. Although accurate distances among the genes and markers require further study, all these data indicate that $\mathrm{YrSP}$ is at a different locus from $\mathrm{Yr} 43, \mathrm{Yr} 44$, and $\mathrm{Yr} 53$.

In addition to the permanently named genes, Deng et al. (2004) located $\mathrm{YrQz} 5.66 \mathrm{cM}$ from marker Xgwm388 in chromosome 2B. Based on the much larger distance between Xgwm388 and $\mathrm{YrSP}$ $(17.6 \mathrm{cM})$ in the present study, $\mathrm{YrSP}$ is likely different from $\operatorname{Yr} Q z$. $Y r S P$ has not been allocated a permanent gene designation because of conflicting data regarding its allelism, or otherwise closely linked with $Y r 5$ and $Y r 7$. Although the present work strongly suggests that the genes are at different loci, there is already one report (Zhang et al. 2009) that the latter two genes are allelic. The present allelism tests were based on $\mathrm{F}_{2}$ phenotypes and neither the resistant plants nor susceptible plants were progeny tested. New populations under increase will be tested as $\mathrm{F}_{2: 3}$ populations, a much more efficient process for assessing duplicate dominant genes in repulsion.

MAS has become increasingly important in breeding programs, because it permits breeders to combine genes for important traits, including multiple genes for resistance to a single disease, thereby contributing to both enhanced levels of resistance (in some situations) and resistance durability (Chen 2013; Cheng et al. 2014; Lu et al. 2014; $\mathrm{Xu}$ et al. 2013). However, one of the limitations of MAS for breeding is lack of closely linked diagnostic markers for targeted traits. In the present study, we identified several markers closely linked to $\mathrm{YrSP}$. We tested Xwmc332, $d p 269$, and Xwmc441 in 77 wheat cultivars or lines that do not have the YrSP line or Spaldings Prolific in their pedigrees, and found that $97 \%$ of the cultivars or lines do not have at least one of the marker alleles identified in AvSYrSPNIL. These markers in combination should be useful in MAS to combine $\operatorname{YrSP}$ with other effective genes. Although $\mathrm{YrSP}$ is race specific, it provides resistance to a broad range of $P$. striiformis f. sp. tritici races in the United States and other countries (Sharma-Poudyal et al. 2013; Wan and Chen 2014) and could be valuable when combined with other $\mathrm{Yr}$ genes but, if used alone, would be unlikely to provide durable resistance because of continuing reports of occasional virulent isolates in race surveys. Because the identified chromosome $2 \mathrm{BL}$ region contains several genes, we are currently attempting to combine $\mathrm{YrSP}$ with $\mathrm{Yr} 5$ and $\mathrm{Yr} 53$ in the same region because the latter two are effective against all $P$. striiformis $\mathrm{f}$. sp. tritici races tested in the present and previous studies (Wan and Chen 2014; Xu et al. 2013; Yan et al. 2003). In addition to developing resistant cultivars, the results of the present study indicate that $\operatorname{YrSP}$ should be useful in differentiating $P$. striiformis $\mathrm{f}$. sp. tritici races and studying the plant-pathogen interactions.

\section{ACKNOWLEDGMENTS}

This research was supported by the USDA-ARS (project number 5348-22000-015-00D) and Washington State University (project number 13C-3061-5665 and 13Z-3061-6665). We thank the China Scholarship Council for the scholarship to J. Feng, D. Jiwan for technical assistance in Sequenom SNP genotyping, and R. McIntosh for critical review of the 
manuscript. Mention of trade names or commercial products in this publication is solely for the purpose of providing specific information and does not imply recommendation or endorsement by the U.S. Department of Agriculture. USDA is an equal opportunity provider and employer.

\section{LITERATURE CITED}

Allan, R. E., and Purdy, L. H. 1970. Reaction of $\mathrm{F}_{2}$ seedlings of several crosses of susceptible and resistant wheat selections to Puccinia striiformis. Phytopathology 60:1368-1372.

Calonnec, A., Goyeau, H., and Vallavieille-Pope, C. 1996. Effects of induced resistance on infection efficiency and sporulation of Puccinia striiformis on seedlings in varietal mixtures and on field epidemics in pure stands. Eur. J. Plant Pathol. 102:733-741.

Cavanagh, C. R., Chao, S., Wang, S., Huang, B. E., Stephen, S., Kiani, S., and Akhunov, E. 2013. Genome-wide comparative diversity uncovers multiple targets of selection for improvement in hexaploid wheat landraces and cultivars. Proc. Natl. Acad. Sci. USA 110:8057-8062.

Chen, X. M. 2005. Epidemiology and control of stripe rust (Puccinia striiformis f. sp. tritici) on wheat. Can. J. Plant Pathol. 27:314-337.

Chen, X. M. 2013. High-temperature adult-plant resistance, key for sustainable control of stripe rust. Am. J. Plant Sci. 4:608-627.

Chen, X. M. 2014. Integration of cultivar resistance and fungicide application for control of wheat stripe rust. Can. J. Plant Pathol. 36:311-326.

Chen, X. M., and Line, R. F. 1995. Gene action in wheat cultivars for durable high-temperature adult-plant resistance and interactions with race-specific, seedling resistance to stripe rust caused by Puccinia striiformis. Phytopathology 85:567-572

Chen, X. M., Line, R. F., and Leung, H. 1995. Virulence and polymorphic DNA relationships of Puccinia striiformis f. sp. hordei to other rusts. Phytopathology 85:1335-1342.

Chen, X. M., Penman, L., Wan, A. M., and Cheng, P. 2010. Virulence races of Puccinia striiformis f. sp. tritici in 2006 and 2007 and development of wheat stripe rust and distributions, dynamics, and evolutionary relationships of races from 2000 to 2007 in the United States. Can. J. Plant Pathol. 32: 315-333.

Chen, X. M., Soria, M. A., Yan, G. P., Sun, J., and Dubcovsky, J. 2003. Development of sequence tagged site and cleaved amplified polymorphic sequence markers for wheat stripe rust resistance gene Yr5. Crop Sci. 43: 2058-2064.

Cheng, P., and Chen, X. M. 2010. Molecular mapping of a gene for stripe rust resistance in spring wheat cultivar IDO377s. Theor. Appl. Genet. 121: 195-204.

Cheng, P., Xu, L. S., Wang, M. N., See, D. R., and Chen, X. M. 2014. Molecular mapping of genes Yr64 and Yr65 for stripe rust resistance in hexaploid derivatives of durum wheat accessions PI 331260 and PI 480016. Theor. Appl. Genet. 127:2267-2277.

Deng, Z. Y., Zhang, X. Q., and Wang, X. P. 2004. Identification and molecular mapping of a stripe rust resistance gene from a common wheat line Qz180. Acta Bot. Sin. 46:236-241.

de Vallavieille-Pope, C., and Line, R. F. 1990. Virulence of North American and European races of Puccinia striiformis on North American, world, and European differential wheat cultivars. Plant Dis. 74:739-743.

Endo, T. R., and Gill, B. S. 1996. The deletion stocks of common wheat. J. Hered. 87:295-307.

Fang, T. L., Chang, Y., Li, G. Q., Xu, S. C., Xie, C. J., You, M. S., Yang, Z. M., Sun, Q. X., and Liu, Z. Y. 2008. Molecular characterization of a stripe rust resistance gene from wheat line S2199 and its allelism with $\mathrm{Yr}$. Acta Agron. Sin. 34:355-360.

Gassner, G., and Straib, W. 1932. Bestimmung der biologischen Rassen des Weizengelbrostes (Puccinia glumarum f. sp. tritici (Schmidt) Erikss. u. Henn.). Arb. Biol. Reichsanst. Land Forstwirtsch. Berlin-Dahlem 20: 141-163.

Gosal, K. S. 2000. Aspects of resistance to wheat stripe rust in Australia. Ph.D. thesis, The University of Sydney, Sydney, Australia.

Guan, H. T., Guo, Y. H., Wang, Y. B., Liu, T. G., Lin, R. M., and Xu, S. C. 2005. Microsatellite marker of the resistance gene $\mathrm{YrSpP}$ to wheat stripe rust. Sci. Agric. Sin. 38:1574-1577.

Johnson, R., Stubbs, R. W., Fuchs, E., and Chamberlain, N. H. 1972. Nomenclature for physiologic races of Puccinia striiformis infecting wheat. Trans. Br. Mycol. Soc. 58:475-480.

Kosambi, D. D. 1943. The estimation of map distance from recombination values. Ann. Eugen. 12:172-175.

Line, R. F. 2002. Stripe rust of wheat and barley in North America: A retrospective historical review. Annu. Rev. Phytopathol. 40:75-118.

Line, R. F., and Qayoum, A. 1992. Virulence, aggressiveness, evolution, and distribution of races of Puccinia striiformis (the cause of stripe rust of wheat) in North America, 1968-87. U. S. Dep. Agric. Agric. Res. Serv. Tech. Bull. No. 1788.
Liu, R. H., and Meng, J. L. 2003. MapDraw: A Microsoft Excel macro for drawing genetic linkage maps based on given genetic linkage data. Hereditas 3:317-321.

Lu, Y., Wang, M. N., Chen, X. M., See, D. R., Chao, S. M., and Jing, J. X. 2014. Mapping of $\operatorname{Yr} 62$ and a small-effect QTL for high-temperature adultplant resistance to stripe rust in spring wheat PI 192252. Theor. Appl. Genet. 127:1449-1459.

Manners, J. G. 1950. Studies on the physiologic specialization of yellow rust (Puccinia glumarum (Schm.) Erikss. \& Henn.) in Great Britain. Ann. Appl. Biol. 37:187-214.

McDonald, D. B., McIntosh, R. A., Wellings, C. R., Singh, R. P., and Nelson, J. C. 2004. Cytogenetical studies in wheat XIX. Location and linkage studies on gene $Y r 27$ for resistance to stripe (yellow) rust. Euphytica 136:239-248.

McIntosh, R. A., Wellings, C. R., and Park, F. 1995: Page 200 in: Wheat Rusts: An Atlas of Resistance Genes. CSIRO, Australia. Kluwer Academic Publishers, Dordrecht, The Netherlands.

McIntosh, R. A., Yamazaki, Y., Dubcovsky, J., Rogers, J., Morris, C., Appels, R., and Xia, X. C. 2013. Catalogue of gene symbols for wheat. In: 12th Int. Wheat Genet. Symp. Yokohama, Japan. Online publication. http://www. shigen.nig.ac.jp/wheat/komugi/genes/download.jsp

Michelmore, R. W., Paran, I., and Kesseli, R. V. 1991. Identification of markers linked to disease resistance genes by bulked segregant analysis: A rapid method to detect markers in specific genomic regions using segregation populations. Proc. Natl. Acad. Sci. USA 88:9828-9832.

Murphy, L. R., Santra, D., Kidwell, K., Yan, G. P., Chen, X. M., and Campbell, K. G. 2009. Linkage maps of wheat stripe rust resistance genes $Y r 5$ and Yr15 for use in marker assisted selection. Crop Sci. 49:1786-1790.

Riede, C. R., and Anderson, J. A. 1996. Linkage of RFLP markers to an aluminum tolerance gene in wheat. Crop Sci. 36:905-909.

Röder, M. S., Korzun, V., and Wendehake, K. 1998. A microsatellite map of wheat. Genetics 149:2007-2023.

Sears, E. R. 1966. Nullisomic-tetrasomic combinations in hexaploid wheat. Pages 29-45 in: Chromosome Manipulations and Plant Genetics. R. Riley and K. R. Lewis, eds. Oliver and Boyd, Edinburgh.

Sears, E. R., and Sears, L. M. S. 1978. The telocentric chromosomes of common wheat. Pages 389-407 in: Proc. 5th Int. Wheat Genet. Symp. R. Ramanujan, ed. Indian Soc. Genet. Plant Breed., Indian Agric. Res. Inst., New Delhi, India.

Sharma-Poudyal, D., Chen, X. M., Wan, A. M., Zhan, G. M., Kang, Z. S., Cao, S. Q., Jin, S. L., Morgounov, A., Akin, B., Mert, Z., Shah, S. J. A., Bux, H., Ashraf, M., Sharma, R. C., Madariaga, R., Puri, K. D., Wellings, C., Xi, K. Q., Wanyera, R., Manninger, K., Ganzález, M. I., Koyda, M., Sanin, S., and Patzek, L. J. 2013. Virulence characterization of international collections of the wheat stripe rust pathogen, Puccinia striiformis f. sp. tritici. Plant Dis. 97:379-386.

Somers, D. J., Isaac, P., and Edwards, K. 2004. A high-density microsatellite consensus map for bread wheat (Triticum aestivum L.). Theor. Appl. Genet. 109:1105-1114.

Sourdille, P., Singh, S., Cadalen, T., Brown-Guedira, G. L., Gay, G., Qi, L., Gill, B. S., Dufour, P., Murigneux, A., and Bernard, M. 2004. Microsatellite-based deletion bin system for the establishment of genetic physical map relationships in wheat (Triticum aestivum L.). Funct. Integr. Genomics 4:12-25.

Straib, W. 1934. Untersuchungen zur Genetik der Gelbrotresistenz des Weizens. Phytopathol. Z. 7:427-477.

Stubbs, R. W. 1967. Influence of light on the reactions of wheat and barley seedlings to Puccinia striiformis. Phytopathology 57:615-619.

Stubbs, R. W. 1985. Stripe rust. Pages 61-101 in: The Cereal Rusts. Vol. II, Disease, Distribution, Epidemiology and Control. A. P. Roelfs and W. R. Bushnell, eds. Academic Press, Orlando, FL.

Stubbs, R. W. 1988. Pathogenicity analysis of yellow (stripe) rust of wheat and its significance in a global context. Pages 23-38 in: Breeding Strategies for Resistance to the Rusts of Wheat. N. W. Simmonds and S. Rajaram, eds. CIMMYT, Mexico.

Sui, X. X., Wang, M. N., and Chen, X. M. 2009. Molecular mapping of a stripe rust resistance gene in spring wheat cultivar Zak. Phytopathology 99: 1209-1215.

Voorrips, R. E. 2002. MapChart: Software for the graphical presentation of linkage maps and QTLs. J. Hered. 93:77-78.

Wan, A. M., and Chen, X. M. 2012. Virulence, frequency, and distribution of races of Puccinia striiformis f. sp. tritici and P. striiformis f. sp. hordei identified in the United States in 2008 and 2009. Plant Dis. 96:67-74.

Wan, A. M., and Chen, X. M. 2014. Virulence characterization of Puccinia striiformis f. sp. tritici using a new set of $Y r$ single-gene line differentials in the United States in 2010. Plant Dis. 98:1534-1542.

Wellings, C. R. 2011. Global status of stripe rust: A review of historical and current threats. Euphytica 179:129-141.

Wellings, C. R., and McIntosh, R. A. 1990. Puccinia striiformis f. sp. tritici in Australia: Pathogenic changes during the first 10 years. Plant Pathol. 39: 316-325. 
Wellings, C. R., Singh, R. P., McIntosh, R. A., and Pretorius, Z. A. 2004. The development and application of near isogenic lines for the stripe (yellow) rust pathosystem. Page A1.39 in: Proc. 11th Int. Cereal Rusts Powdery Mildew Conf. Norwich, England. Cereal Rusts and Powdery Mildews Bull. Online publication. www.crpmb.org/icrpmc11/abstracts.htm

Xu, L. S., Wang, M. N., Cheng, P., Kang, Z. S., Hulbert, S. H., and Chen, X. M. 2013. Molecular mapping of Yr53, a new gene for stripe rust resistance in durum wheat accession PI 480148 and its transfer to common wheat. Theor. Appl. Genet. 126:523-533.
Yan, G. P., Chen, X. M., Line, R. F. and Wellings, C. R. 2003. Resistance gene analog polymorphism markers co-segregating with the $Y r 5$ gene for resistance to wheat stripe rust. Theor. Appl. Genet. 106:636-643.

Yao, Z. J., Lin, R. M., Xu, S. C., Li, Z. F., Wan, A. M., and Ma, Z. Y. 2006. The molecular tagging of the yellow rust resistance gene $Y r 7$ in wheat transferred from differential host Lee using microsatellite markers. Sci. Agric. Sin. 39:1146-1152

Zhang, P., McIntosh, R. A., Hoxha, S., and Dong, C. 2009. Wheat stripe rust resistance genes $Y r 5$ and $Y r 7$ are allelic. Theor. Appl. Genet. 120:25-29. 